Exp. Anim. 40(1), 95-99, 1991

\title{
Pathological Evaluation of Anti-rheumatic Drugs on Type II Collagen-induced Arthritis in DBA/1J Mouse
}

\author{
Kazunori IMAIZUMI, Hiromi HINOUE, Makoto UENO,* \\ Isao TAKATA*, Tadashi SATO*, Yoshio MINATO, \\ Masakazu TAKESHITA, and Azusa OKANIWA \\ Safety Research Laboratory and * Research Laboratory of Applied \\ Biochemistry, Tanabe Seiyaku Co., Ltd, 3-16-89 Kashima, \\ Yodogawa-ku, Osaka-shi, Osaka 532, Japan
}

(Received 18 May 1990/Accepted 17 July 1990)

\begin{abstract}
The effects of anti-rheumatic drugs (lobenzarit (CCA); 10 and $50 \mathrm{mg} / \mathrm{kg}$, cyclophosphamide (CP) $; 5 \mathrm{mg} / \mathrm{kg}$ and dexamethasone (DM) $; 0.25 \mathrm{mg} / \mathrm{kg}$ ) were evaluated immunologically and histopathologically on DBA/1J mice that develop polyarthritis after immunization by the intradermal injection of type II collagen. Serum anti-type II collagen IgG levels in the groups treated with CP and DM were significantly suppressed to $1 / 2$ and $1 / 10$ as compared to those of the positive control group, respectively. Those of both groups treated with CCA were not different from those of the positive control group. Histopathological examination revealed that treatment with CP and DM markedly reduced or suppressed inflammatory changes and resulted in low incidence of arthritis. From the standpoint mentioned above, treatment with anti-rhematic drugs suppressed the development of arthritis in this model, and we could confirmthat this model was useful for evaluation of the effect of anti-rheumatic drugs.
\end{abstract}

$\mathrm{DBA} / 1 \mathrm{~J}$ mouse is known to develop polyarthritis after immunization by the injection of type II collagen [2, 3,6,14], and recently it arouses general interest as an experimental model of human rheumatoid arthritis. Previous histological examination revealed that the sequence of arthritic lesions was not uniform by each joint [4]. Evaluation of the effects of anti-rheumatic drugs had been conducted in this model using macroscopic or immunologic criteria by Phadke et al. [10], Paska et al. [9] and etc.

In the present study as the second series of experiments dealing with type II collagen induced polyarthritis in DBA/1J mouse, anti-rheumatic drugs of different categories were administered to the model animals and the limb joints were examined histopathologically to investigate the feasibility of this model for the evaluation of anti-rhematic agents.

DBA $/ 1 \mathrm{~J}$ mice were purchased from Jackson
Laboratory (Bar Harbor, ME), and were 7 weeks of age at the starting time of the experiment. Experimental groups consisted of 6 groups, that was, the negative (intact) and positive (treated with type II collagen) control groups and lobenzarit (CCA ; 10 and $50 \mathrm{mg} / \mathrm{kg}$ ), cyclophosphamide $(\mathrm{CP} ; 5 \mathrm{mg} / \mathrm{kg})$ and dexamethasone (DM ; $0.25 \mathrm{mg} / \mathrm{kg}$ ) treatment groups, and 6 animals were assigned for each group (Table 1). The dose of CCA was determined as 10 and $50 \mathrm{mg} / \mathrm{kg}$ referred to the reports by Mihara et al. [7] and Abe et al. [1]. The dose of CP was based on the reports by Phadke et al. [9] and the dose of DM was referred to the report by Komoriya et al. [5].

The animals of each group except the negative control group were intradermally injected with an emulsion of type II collagen $(100 \mu \mathrm{g}$ /body) dissolved in $0.05 \mathrm{M}$ acetic acid at $1 \mathrm{mg} /$ $\mathrm{ml}$ and an equal volume of complete Freund's adjuvant at the base of the tail (first immuni- 
Table 1. Experimental groups

\begin{tabular}{llccc}
\hline Experimental drugs & $\begin{array}{c}\text { Dose } \\
(\mathrm{mg} / \mathrm{kg})\end{array}$ & Immunization & $\begin{array}{c}\text { No. of } \\
\text { animals }\end{array}$ \\
\hline 1. & Positive control & - & - & 6 \\
2. & Negative control & - & + & 6 \\
3. Lobenzarit (CCA) & 10 & + & 6 \\
4. Lobenzarit (CCA) & 50 & + & 6 \\
5. Cyclophosphamide (CP) & 5 & + & 6 \\
6. & Dexamethasone (DM) & 0.25 & + & 6 \\
\hline
\end{tabular}

zation). Furthermore one week later, the same treatment (as the second immunization) was applied. The animals of the negative control group received equivalent amounts of complete Freund's adjuvant in $0.05 \mathrm{M}$ acetic acid alone. The experimental animals were orally treated with the test drugs 5 days a week (once a day) for 12 weeks from the day of the first immunization. The animals of the negative and positive control groups were treated with suspension of $0.2 \%$ carboxymethylcellulose in physiological saline. All animals were bled by decapitation for measurement of serum anti-type II collagen antibody levels 12 weeks after the start of dosing, and the limb joints were examined histopathologically.

Macroscopical observation : Gross lesions of each joint in all animals were scored on the scale of $0-2$ according to the scoring method reported previously (Arthritis score) [4], and the score of one animal was calculated as a total of scores of four limbs (the score will be 8 at the maximum). In the positive control group, clinical onset of arthritis was observed 4 or 5 weeks after the first immunization, and the arthritis score at 12 weeks after the immunization reached near the 8 point level which was the highest value. The score of the groups treated with $\mathrm{CP}$ and DM remained unchanged except slight elevation late in the observation period. That of mice of both groups treated with CCA was not different from that of the positive control group (Fig. 1).

Measurement of serum anti-type II collagen antibody : Serum anti-type II collagen IgG levels were measured by enzyme-linked immunosorbent assay (ELISA). In the groups treated with CP and DM the level of anti-type II collagen IgG were significantly suppressed to $1 / 2$ and $1 / 10$ as compared to those of the positive control, respectively. Those of both groups treated with CCA were not different from those

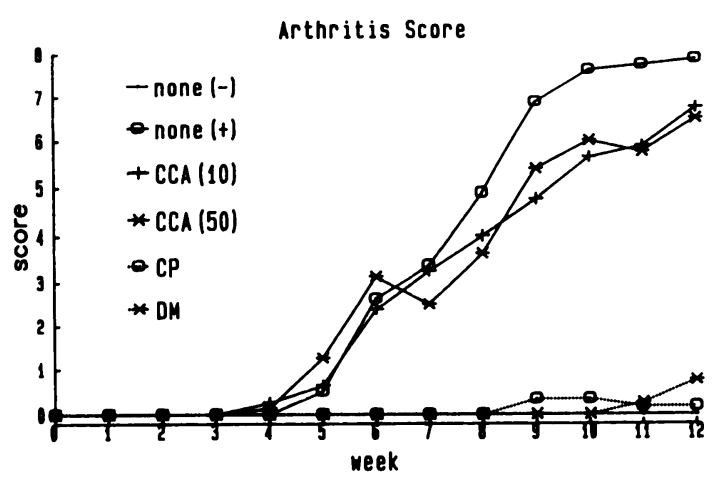

Fig. 1. Arthritis score

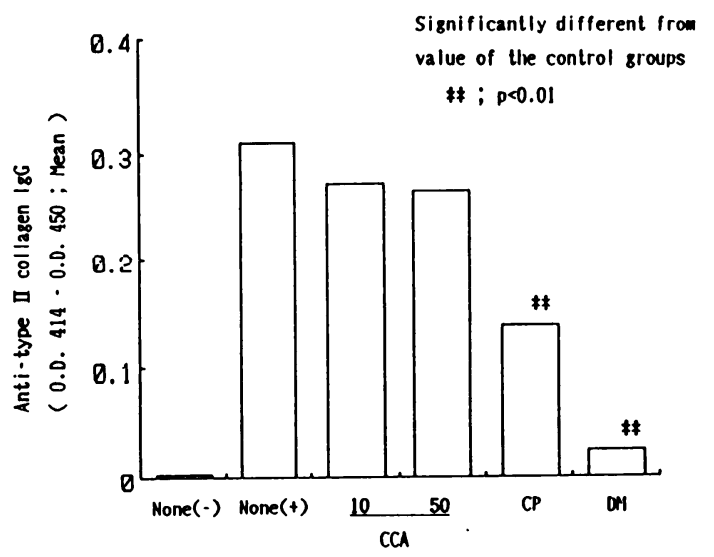

Fig. 2. Serum anti-type II collagen IgG levels

of the positive control group (Fig. 2).

Histopathological examination : The limb joints of all animals were fixed in $10 \%$ buffered neutral formalin solution and were decalcified by $5 \%$ formic acid. Paraffin sections were prepared by the routine method and histopathological examination was conducted.

In the previous study, all of the joints of one leg showed a tendency to develop arthritis 

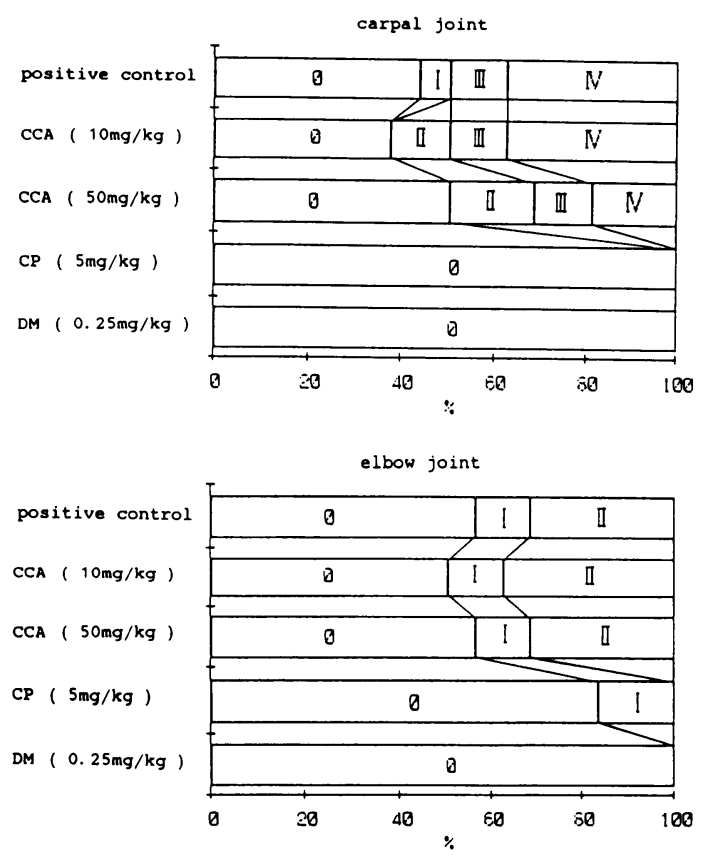

Fig. 3. Histopathological characteristics in each joint of forelimbs 0 : No development of arthritis I : Proliferation of synovial lining cells II : Formation of granulation tissue with destruction of subchondral bone III : Fibrous ankylosis N : Bony ankylosis

at the same time when the animals immunized with type II collagen [4]. Referring to this result, a total of 8 joints, left and right carpal, tarsal, elbow and knee joints from each individual were histopathologically examined in the present study. The same grading system described in the previous study was employed, i. e. 0 : no development of arthritis, I : proliferation of synovial lining cells and neutrophil infiltration, II : formation of granulation tissue with destruction of articular cartilage and subchondral bone, III : fibrous ankylosis, IV : bony ankylosis (ref. 4 ; Fig. 4-8).

Morbidity rate of arthritic lesion and histopathological characteristics in each joint of forelimbs and hindlimbs are shown in Fig. 3 and Fig. 4 . In the group treated with DM, no changes were observed in each joint of all animals at all. In the group treated with $\mathrm{CP}$, no histopathological changes were observed in the carpal and tarsal joints and only such slight changes as the proliferation of synovial lining cells,
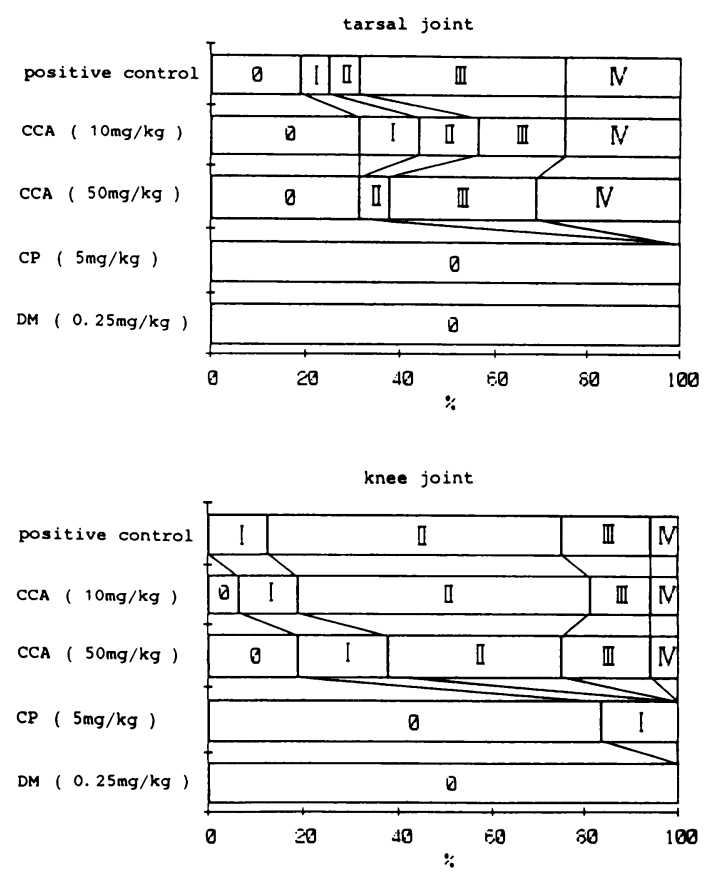

Fig. 4. Histopathological characteristics in each joint of hindlimbs

and neutrophil infiltration and fibroblast proliferation directly under synovial lining cells (grade I) were observed in a few elbow and knee joints (Fig. 5 and Fig. 6). These changes were observed in 3 out of 6 animals treated with CP. The morbidity rate of arthriris and histopathological characteristics of lesions in both groups treated with CCA were not different from those of the positive control.

Thus it was definitely shown that treatment with $\mathrm{CP}$ and DM markedly reduced or suppressed inflammatory changes and resulted in low incidence of arthritis.

The development of arthritis in $\mathrm{DBA} / 1 \mathrm{~J}$ mouse induced by type II collagen is known to be closely associated with humoral and cellular autoimmunity to type II collagen [11-13]. In consistent with previous studies, treatment with $\mathrm{CP}$ an immunosuppressant and $\mathrm{DM}$ a steroidal anti-inflammatory drug suppressed the elevation of serum anti-type II collagen IgG levels, and also reduced histopathological lesions or suppressed the development of arthritis. Phadke et al. also reported that treatment with paramethasone a steroidal anti-inflammatory drug and CP suppressed the elevation of an- 


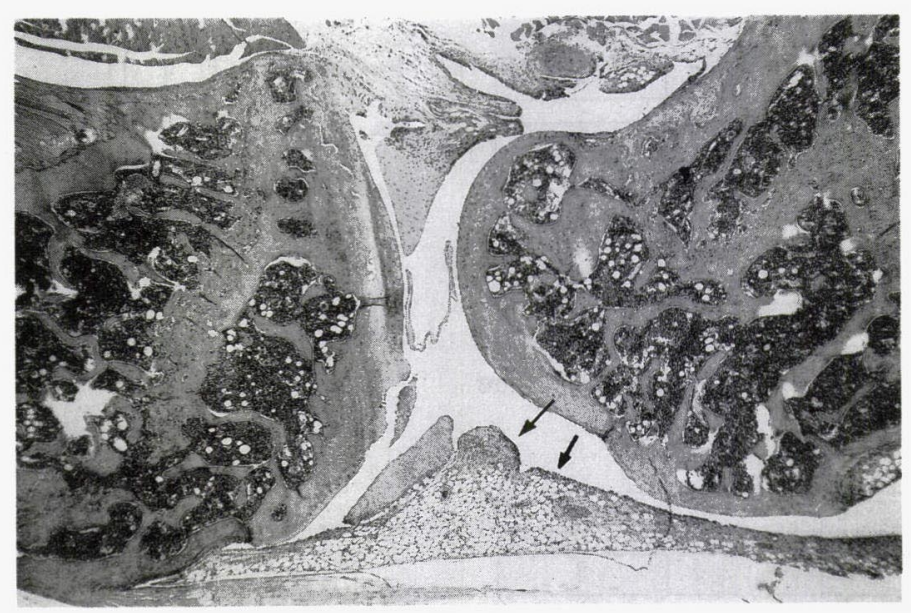

Fig. 5. Slight change at the synovial membrane (arrow) in the knee joint treated with $\mathrm{CP}$ HE stain $\times 30$

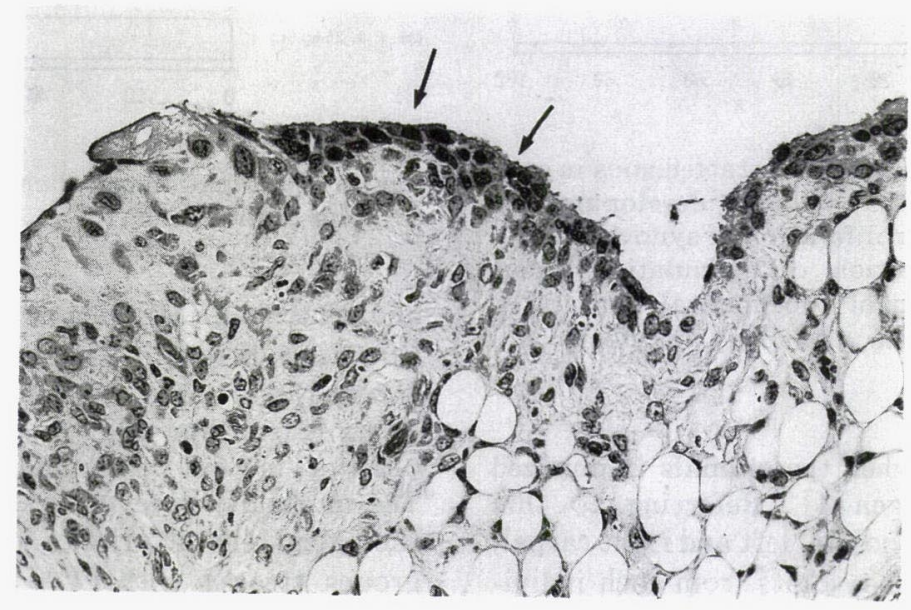

Fig. 6. Magnification of Fig. 5. Stratified proliferation of synovial lining cells (arrow), and fibroblast proliferation $\times 280$

tibody levels and macroscopical development of arthritis [10]. Steroidal anti-inflammatory drugs and immunosuppressants are used against rheumatoid arthritic patients, the former is known to affect the inflammatory response by suppressing the production of arachidonic acid cascade, the latter to suppress immune response by suppression of cell division and proliferation to inhibit metabolism of nucleic acid $[8,16]$.

Both groups treated with 10 and $50 \mathrm{mg} / \mathrm{kg}$ of CCA an immunomodulator, did not suppress the development of arthritis in this study.
Phadke et al. [10] and Paska et al. [9], who treated the animals in the same model as the present study with $\mathrm{D}$-penicillamine and gold chlorophosphene which were known as immunomodulators and reported that these drugs did not suppress the development of macroscopic arthritis. Thus it seems unlikely that treatment with immunomodulators at least at the doses employed in these experimental conditions affect the development of polyarthritis in this model. However, as it is known that the doses that the effects of immunomodulators occur, 
show so-called bell-shape pattern [15]. Therefore the possibility of evaluation of the effects of immunomodulators on this model requires further examination.

\section{References}

[1] Abe, C., Shiokawa, Y., Ohishi, T., Hata, S., and Takagaki, T. (1981). The Ryumachi 21, 165-170.

[2] Courtenay, J.S., Dallman, M. J., Dayan, A. D., Martin, A., and Mosdale, B.(1980). Nature, 283, 666-668.

[3] Hirofuji, T., Kakimoto, K., and Koga, T. (1986). Fukuoka acta medica 77, 185-193.

[4] Imaizumi, K., Hinoue, H., Ueno, M., Takata, I, Sato, T, Minato, Y, Takeshita, M., and Okaniwa, A. (1990). Exp Anim,39, 27-34.

[5] Komoriya, I., Nagata, I., Kunisawa, K., Takeshita, T., and Naruchi, T. (1987). Japan J. Pharmacol, 45, 389-396.

[6] Koga, T., Kakimoto, K., Tanaka, T., Hirofuji, T., and Sumiyoshi, A. (1982). Japanese journal of inflamma- tion, 2, 503-504

[7] Mihara, M. and Ohsugi, Y. (1989). Japanese journal of inflammation, 9, 55-59.

[8] Nishioka, J. (1988). Medicine and Drug Journal 24, 2149-2153.

[9] Paska, W., McDonald, K. J., and Croft, M. (1986). Agents and Actions, 18, 413-420.

[10] Phadke, K., Fouts, R. L., Parrish, J. E., and Butler, L. D. (1985). Immunopharmacology, 10, 51-60.

[11] Stuart, J. M., Cremer, M. A., Kang, A. H., and Townes, A. S. (1979) . Arthrit is Rheum, 22, 13441351 .

[12] Stuart, J. M., Townes, A. S., and Kang, A. H.(1982). J. Clin. Invest., 69, 673-683.

[13] Trentham, D. E., Dynesius, R. A., and David, J. R. (1978). J. Clin Invest., 62, 359-366.

[14] Wooley, P. H., Luthra, H, S., Stuart, J. M., and David, C. S. (1981). J. Exp Med, 154, 688-700.

[15] Yamamoto, I., Ohmori, H., and Sasano, M. (1982). Drugs Exptl Clin Res 8, 5-10.

[16] Yoshida, H. (1988). Medicie and Drug Journal 24, 2191-2197.

\section{II 型コラーゲン感作 DBA/1J マウスを用いた 抗リウマチ薬の病理学的薬効評価 \\ 今泉和則・确ノ上ひろみ・上野 誠*.高田 功*. 佐藤忠司*·湊良雄・武下政一.岡庭梓

\author{
田辺製薬柇宔性研究所 \\ *田辺製薬㑣店生化学研究所
}

II 型コラーゲンの皮内注射により多発性関節炎を発症 する DBA/1 J マウスを用いて抗りウマチ桼（ロベンザ リット (CCA), シクロフォスファミド (CP) およびデ キサメタゾン (DM)) の薬効を血清抗】型コラーゲン抗 体価の測定および病理組織学的検査により検討した。そ の結果, CCA 群では抗体価および関節の病理組織学的
変化は陽性対照群のそれと同程度のものであったが， $\mathrm{CP}$ 群および DM 群では抗体価はそれぞれ約 $1 / 2$ およ゙゙ 約 $1 / 10$ 亿低下し, 病理組織学的検査では本病態特有の 出性変化および增殖性変化が軽減ないし抑制され, 有病 率も低下した。以上の結果より, 本病態マウスは抗りウ マチ薬の薬効評価に利用可能であることが確認できた。 